\title{
Irradiance Distribution Analysis of a Squid Jigging Vessel Using an LED Plus Metal Halide Fishing Lamp Combination Under Optimized Conditions
}

\author{
Mee Suk Jung ${ }^{1 \dagger}$, Ki Dae Lee ${ }^{1}$, Jae Seok $\mathrm{Ko}^{1}$, and Jae Hyun $\mathrm{Bae}^{2}$ \\ ${ }^{1}$ Department of Nano-optical engineering, Korea Polytechnic University, \\ 237 Sangidaehak-ro, Siheung 429-793, Korea \\ ${ }^{2}$ Aquaculture Industry Division, East Sea Fisheries Research Institute, NFRDI, Gangneung 210-861, Korea
}

(Received November 3, 2014; Revised manuscript December 1, 2014; Accepted December 4, 2014)

\begin{abstract}
A combination of MHL and LED fish-luring light is used in this study. Its yield, characteristics, and irradiance distribution are evaluated and analyzed. To obtain an irradiance distribution similar to that of an MHL, we suggest the optimal arrangement of MHL and LED.
\end{abstract}

Keywords: Fish-luring light, Metal halide lamp, LED, Irradiance, Irradiance distribution

OCIS codes: (010.4450) Oceanic optics; (010.5630) Radiometry; (220.2945) Illumination design; (230.3670) Light-emitting diodes

\section{메탈할라이드와 엘이디 오징어 집어등의 겸용시 배치조건에 따른 수중조도분포 비교분석}

\author{
정미숙 $^{\dagger} \cdot$ 이기대 ${ }^{1} \cdot$ 고재석 ${ }^{1} \cdot$ 배재현 $^{2}$ \\ 1한국산업기술대학교 나노광공학과 \\ (우 429-793 경기도 시흥시 산기대학로 237번지 \\ ${ }^{2}$ 국립수산과학원 동해수산연구소 해역산업과 \\ (ㅇ) 210-861 강원도 강릉시 연곡면 해안로 1194 번지
}

(2014년 11월 3일 받음, 2014년 12월 1일 수정본 받음, 2014년 12월 4일 게재 확정)

\begin{abstract}
어류를 잡기 위한 기존의 여러 방법 중 하나로, 한국과 일본에서는 광원을 이용해 오징어를 잡는 방법이 주로 행하여져 왔다. 사용된 광원으로는 메탈할라이드를 이용한 방법이 주로 이용되었으나 유가 상승으로 인한 유지비용 상승이 문제로 대두되어져 왔다. 또한 메탈할라이드 광원은 고온으로 인한 화상의 위험과 인체에 유해한 자외선 스펙트럼 방출로 인하여 어업인의 건강을 위협하여 왔다. 이에 반해 엘이디 광원은 저전력, 저발열의 장점을 가지고 있어서 메탈할라이드 광원을 대체하는 연구가 주로 한국과 일본에서 이루어져 왔으나, 메탈할라이드 광원 대비 낮은 광량과 다른 배광특성으로 인해 어획량은 메탈할라이드 집어등 어선 대비 저조한 실정이다. 이러한 문제점을 해결하고자 본 논문에서는 기존의 메탈할라이드 집어등 어선과 가장 유사한 조도 분포를 얻기 위해 메탈할라이드 광원과 엘이디 광원을 조합 배치하였고, 그때의 수심별 조도 분포 시뮬레이션을 하여 최적의 배치조건을 제시하였다.
\end{abstract}

Keywords: 집어등, 메탈할라이드, 엘이디, 복사조도, 조도분포

OCIS codes: (010.4450) Oceanic optics; (010.5630) Radiometry; (220.2945) Illumination design; (230.3670) Light-emitting diodes

\section{I. 서 론}

채낚기 어업은 우리나라 연근해의 대표적인 어업으로 대략 5,000 척으로 추정되고 있으며 오징어와 갈치를 주 어획대상
으로 하고 있다. 이 중 오징어 채낚기 어업은 동해안의 대표 적인 어업으로써 최근에는 상승하는 유가와 인건비의 상승 으로 어업경영이 매우 어려운 실정이다.

특히 유가는 채낚기 어업의 조업 경비에 큰 영향을 미치는

${ }_{\dagger}^{\dagger}$ E-mail: msoptic@kpu.ac.kr

Color versions of one or more of the figures in this paper are available online. 
데 대부분의 채낚기 어선은 어획고의 $30-40 \%$ 를 유류비로 지 출하고 있어 어업경영을 어렵게 하고 있다. ${ }^{[1]}$

하지만 호빛성 어류를 잡기 위한 어업에서 빛은 매우 중 요한 사항으로 그 이유는 호빛성 어류군이 잡아먹는 플랑크 톤이 빛을 내기 때문이고 어족자원은 주로 그 플랑크톤을 섭 취하기 위해 모여들기 때문이다.

종래에는 광량은 강하지만 소비전력이 많은 메탈할라이드 램프를 집어등으로 사용하여 어업활동에 경제적인 부담으로 작용하여 왔다. 또한 어선에서 배출되는 온실 가스는 지구 온난화에 영향을 미치며, ${ }^{[2]}$ 기존의 메탈할라이드 집어등은 가시영역외의 방출 스펙트럼으로 인하여 시력과 피부 화상 등 어업인의 건강에 악영향을 주고 있다.

따라서 에너지 소모가 적고 발광효율이 우수하면서도 작업 자에게 안전한 광원의 개발이 요구되어 왔다. 최근 기존의 메 탈할라이드 집어등을 보다 전력소모가 적은 엘이디 등으로 교 체하려는 시도가 계속되어져 왔으나 아직은 메탈할라이드 집 어등 대비 낮은 출력과 다른 배광 특성으로 인하여 어획량에 있어서 만족할 만한 성과를 내지는 못하고 있는 실정이다.

본 연구는 우리나라 동해바다의 파장별 투과율을 반영한 해수를 모델링하여 메탈할라이드 집어등의 수중 배광 특성 과 엘이디 집어등의 배광 특성을 비교 분석하고, 메탈할라이 드 집어등과 유사한 조도분포를 나타내는 집어등의 배치조 건을 찾는 것을 목표로 하였다.

\section{II. 메탈 집어등에 의한 수중 배광 특성 시뮬레이션}

기준이 되는 메탈할라이드 어선의 수심별 조도 분포를 알 아보기 위해 먼저 메탈할라이드 광원을 모델링하였고 이를 실제 어선의 집어등 배치를 참고하여 위치시켰다. 그리고 동 해안의 조업철 해수 투과율과 굴절률 데이터를 반영한 해수 를 모델링하였으며 위 조건으로 수심별 조도 분포를 시뮬레 이션 하였다.

\section{1. 메탈할라이드 집어등 모델링}

집어등의 수중 배광 시뮬레이션은 조명광학계 설계 tool인 Lighttools $^{[3]}$ 를 사용하였다. 광원은 소비전력 $1.5 \mathrm{~kW}$ 의 일반

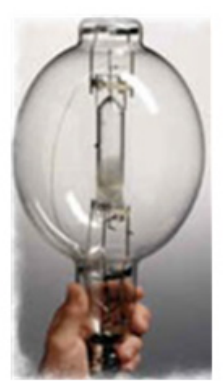

(a)

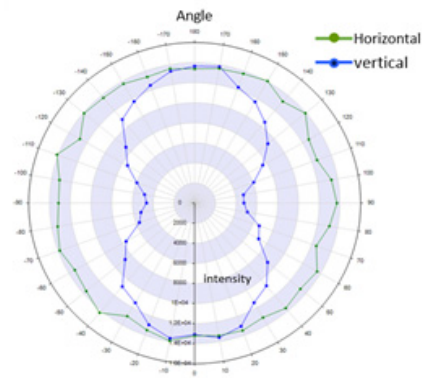

(b)
FIG. 1. (a) Layout and (b) Light distribution of a $1.5 \mathrm{~kW}$ metal halide lamp.

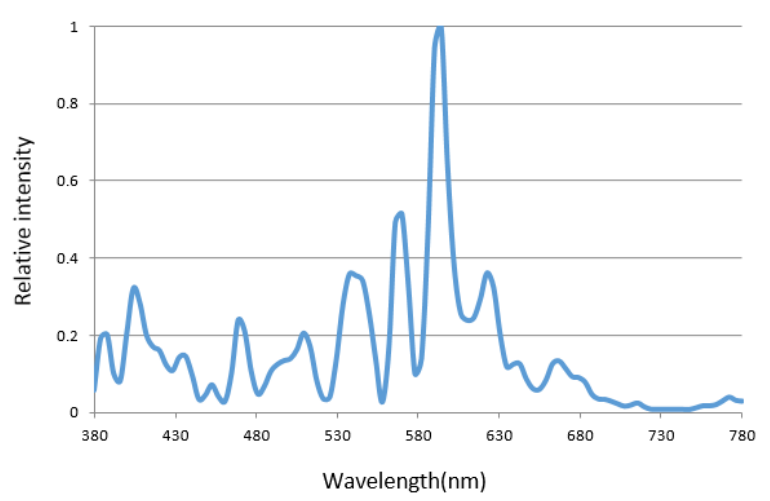

FIG. 2. The spectrum of a metal halide source.
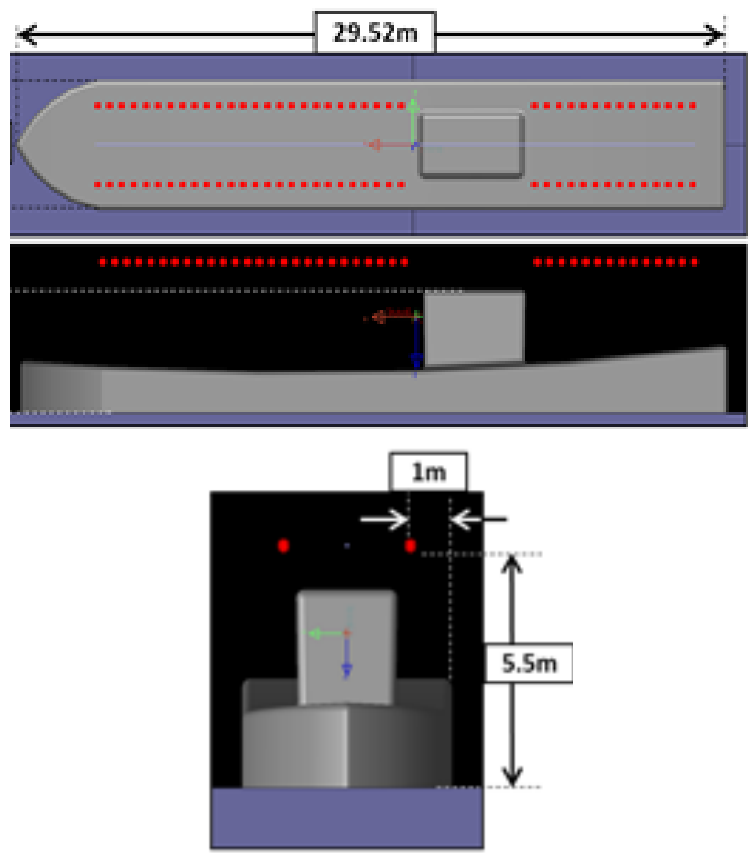

FIG. 3. Installation of a 40-ton jigging vessel model and the metal halide lamps layout.

적인 메탈할라이드 광원 모델을 선택하였으며 광 출력은 $718.42 \mathrm{~W}$ 이다. 메탈할라이드 집어등의 배치와 배광분포는 Fig. 1과 같으며, 메탈할라이드 집어등의 스펙트럼은 Fig. 2 와 같다.

\subsection{0톤 어선 모델링과 메탈할라이드 집어등 배치}

실제 40톤급 어선의 도면을 참조하여 Fig. 3과 같이 총 길 이 $29.52 \mathrm{~m}$, 너비 $5.28 \mathrm{~m}$, 높이 $1.9 \mathrm{~m}$ 의 배 모형을 모델링하 였고, 40톤 어선의 정부기준 제한 소비전력 $120 \mathrm{~kW}$ 에 맞춘 메탈할라이드 집어등 설치 개수는 80 개를 사용하였다. 그리고 집어등의 위치는 배 끝단에서 $1 \mathrm{~m}$ 안쪽이며 높이는 $5.5 \mathrm{~m}$ 이다. 수중 조도분포에 영향을 미치는 해수의 파장별 투과율과 굴절률을 조사하였다. 
TABLE 1. Spectral transmittance of the Type-II

\begin{tabular}{|c|c|c|c|c|c|c|c|c|c|c|c|c|c|c|c|c|}
\hline $\begin{array}{c}\lambda \\
(\mathrm{nm}) \\
\end{array}$ & 310 & 350 & 375 & 400 & 425 & 450 & 475 & 500 & 525 & 550 & 575 & 600 & 625 & 650 & 675 & 700 \\
\hline \multicolumn{17}{|c|}{ 1. Irradiance transmittance $(\% / 0 \mathrm{~m})$} \\
\hline $\begin{array}{c}\text { Type } \\
\text { II }\end{array}$ & 69 & 84 & 89 & 91 & 92.2 & 93.5 & 94 & 93.2 & 92.7 & 91.5 & 89 & 77 & 71.5 & 67 & 63 & 54 \\
\hline \multicolumn{17}{|c|}{ 2. Irradiance transmittance $(\% / 10 \mathrm{~m})$} \\
\hline $\begin{array}{c}\text { Type } \\
\text { II }\end{array}$ & 2.5 & 17 & 30 & 38 & 44 & 51 & 54 & 50 & 47 & 41 & 32 & 7.4 & 3.5 & 1.8 & 0.9 & 0.2 \\
\hline
\end{tabular}

TABLE 2. Spectral attenuation coefficient(k) of the Type-II

\begin{tabular}{c|l|l|l|l|l|l|l|l|l|l|l|l|l|l|l|l}
\hline \hline $\begin{array}{c}\lambda \\
(\mathrm{nm})\end{array}$ & 310 & 350 & 375 & 400 & 425 & 450 & 475 & 500 & 525 & 550 & 575 & 600 & 625 & 650 & 675 & 700 \\
\hline $\begin{array}{c}\text { Type } \\
\text { II }\end{array}$ & 0.34 & 0.16 & 0.11 & 0.09 & 0.07 & 0.06 & 0.05 & 0.06 & 0.07 & 0.08 & 0.1 & 0.23 & 0.3 & 0.36 & 0.42 & 0.56 \\
\hline
\end{tabular}

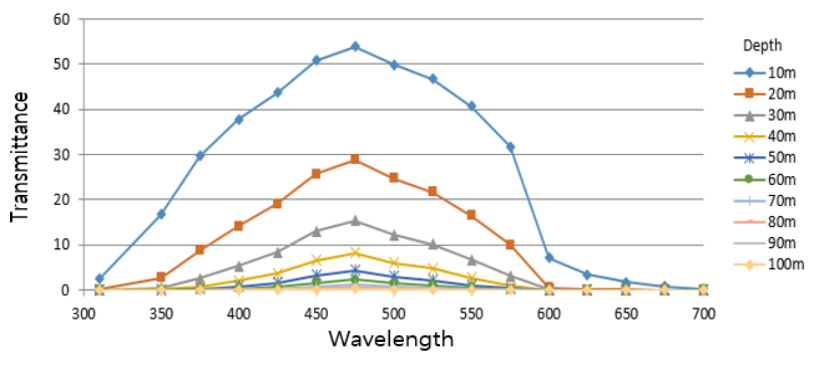

FIG. 4. Spectral transmittance based on attenuation coefficient(k) of the Type-II.

\subsection{1. 동해의 파장별 투과율}

해수의 투과 특성은 파장에 따라 달라지며 N. G. Jerlov는 해양의 따른 투과율을 Table 1 과 같이 제시한 바 있다. ${ }^{[4]}$ 동 해와 가장 근접한 위치의 수형은 Type-II로써 Type-II의 파장 별 투과율을 사용하였다. 그리고 파장에 따른 감쇠 특성을 분석하기 위하여 식 (1)(Beer-Lambert 식)을 이용해 동해의 수심별 소산계수(Attenuation coefficient)를 계산하였다.

$$
\begin{aligned}
& \mathrm{I}(\lambda)=I_{0} \exp (-\mathrm{k}(\lambda) \times \mathrm{z}) \\
& \mathrm{k}(\lambda)=\mathrm{z}^{-1} \times \ln \left(\frac{I_{0}(\lambda)}{I(\lambda)}\right)
\end{aligned}
$$

여기서 $\mathrm{I}(\lambda)$ 는 파장 $\lambda$ 의 하층 복사조도(Intensity of the transmitted radiation), $\mathrm{I}_{0}(\lambda)$ 는 파장 $\lambda$ 의 상층 복사조도(Intensity of the incident radiation), $\mathrm{z}$ 는 상층과 하층의 수심차이 $(\mathrm{m}), \mathrm{k}$ $(\lambda)$ 는 파장 $\lambda$ 의 소산계수를 나타내며, 소산 계수는 빛의 흡 수와 산란으로 인한 빛의 감소를 나타내는 계수이다. 이에 따른 Type- $\Pi$ 수형의 파장별 소산계수는 Table 2 와 같고 이 러한 투과율 데이타를 시뮬레이션 tool에 반영하였다.

동해의 파장별 소산계수에 따른 수심별 투과율 곡선은 Fig. 4

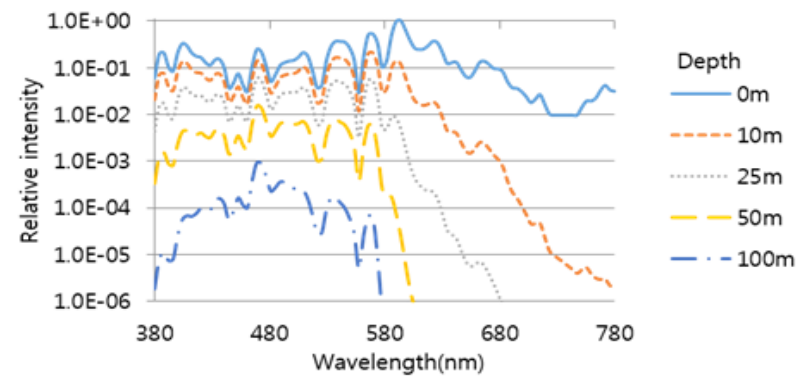

FIG. 5. Spectral transmittance of the metal halide source based on attenuation coefficient $(\mathrm{k})$ of the Type-II.

와 같고 그 소산계수를 반영한 메탈할라이드 집어등의 스펙 트럼은 Fig. 5와 같다.

그래프에서 볼 수 있듯이 적외선 파장대역은 $10 \mathrm{~m}$ 수심 이 후부터는 급격히 감소되는 것을 알 수 있다.

\subsection{2. 동해의 파장별 굴절률 데이타}

해수는 온도, 염분, 파장에 따라 굴절률이 달라지며, R. W. Austin과 G. Halikas는 온도, 염분, 파장에 따른 굴절률을 표 3 과 같이 제시한 바 있다. ${ }^{[5]}$ 국립해양조사원의 자료에 따르 면 동해의 조업철(11월) 평균 수온은 $18^{\circ} \mathrm{C}$, 염분농도는 $33 \% 0$ 이다. ${ }^{[6]}$ 동해의 조업철 수온과 염분농도에 해당하는 파장별 굴절률 데이터를 반영하였다.

\section{3. 해수 모델링과 수심별 검출기 배치}

앞서 반영한 동해 투과 특성과 굴절률이 반영된 해수를 가 로 $400 \mathrm{~m}$, 세로 $400 \mathrm{~m}$, 깊이 $120 \mathrm{~m}$ 의 크기로 Fig. 6과 같이 모델링하였다. 수심별 조도와 조도 분포를 측정하기 위한 검 출기의 위치는 울릉도 어장에서 오징어 어군이 야간에 주로 밀집되어 있다고 보고되어진 수심 ${ }^{[7]} 50 \mathrm{~m} 100 \mathrm{~m}$ 지점중 $80 \mathrm{~m}$, $90 \mathrm{~m}, 100 \mathrm{~m}$ 를 선정하였다. 
TABLE 3. Refractive index(n) based on temperature and salinity of the East Sea fishing period (November)

(Temperature: $18^{\circ} \mathrm{C}$, Salinity: $33 \%$ )

\begin{tabular}{c|c|c|c|c|c|c|c|c|c|c}
\hline \hline$\lambda(\mathrm{nm})$ & 400 & 410 & 420 & 430 & 440 & 450 & 460 & 470 & 480 & 490 \\
\hline $\mathrm{n}$ & 1.349 & 1.348 & 1.347 & 1.347 & 1.346 & 1.345 & 1.345 & 1.344 & 1.343 & 1.343 \\
\hline 500 & 510 & 520 & 530 & 540 & 550 & 560 & 570 & 580 & 590 & 600 \\
\hline 1.342 & 1.342 & 1.341 & 1.341 & 1.340 & 1.340 & 1.340 & 1.339 & 1.339 & 1.339 & 1.338 \\
\hline 610 & 620 & 630 & 640 & 650 & 660 & 670 & 680 & 690 & 700 & \\
\hline 1.338 & 1.338 & 1.338 & 1.337 & 1.337 & 1.337 & 1.336 & 1.336 & 1.336 & 1.336 & \\
\hline
\end{tabular}

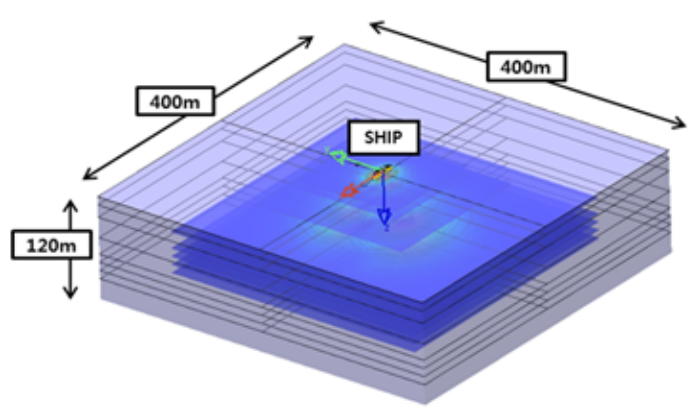

FIG. 6. Sea modeling and detector position.

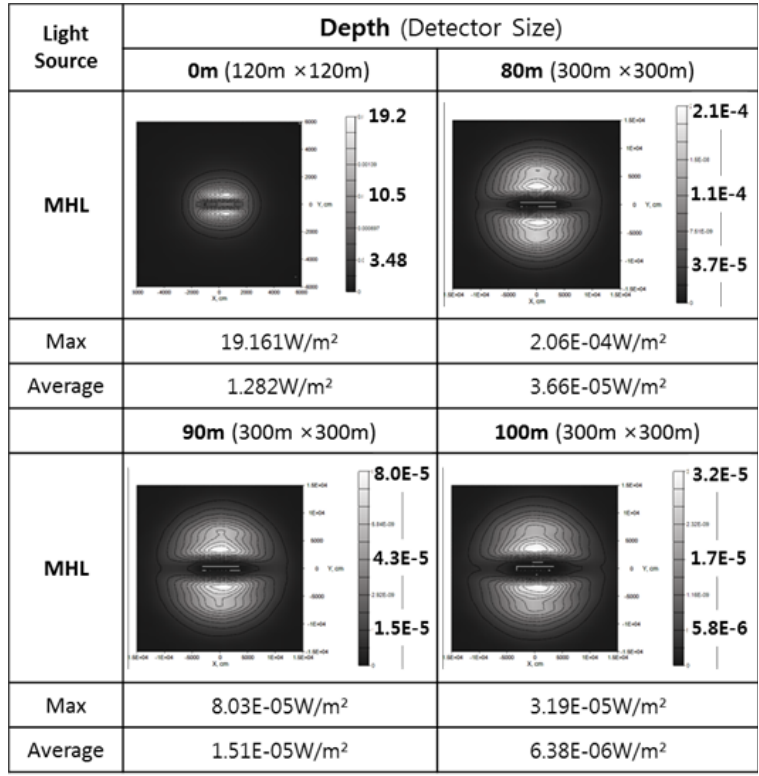

FIG. 7. Simulation results of metal halide irradiance distribution by depth of sea water.

그리고 수심이 깊어짐에 따라 조사되는 영역이 커지므로 수심별 조도 분포에 맞추어 검출기 크기를 달리 설정하였다.

\section{4. 메탈할라이드 집어등의 수심별 조도 분포 시뮬레이션 결과}

위의 조건에서 메탈할라이드 집어등 시뮬레이션에서 수심 별 조도 분포 및 최대/평균조도 값은 Fig. 7과 같고, 평균조 도는 해당 입사면의 총 광량을 검출기의 면적으로 나눈 값으 로 계산되었다.
각 수심별 조도 분포 결과의 상단에 검출기 크기를 표시하 였고 평균조도는 해당 수심 검출기에 입사하는 총 복사속을 검출기 면적으로 나눈 평균 복사 조도 값이며 각 수심별 최 대 복사조도 또한 표시하였다.

\section{III. 엘이디 집어등의 수중 배광 패턴 시뮬레이션}

엘이디 집어등의 수중 조도 분포 시뮬레이션 또한 메탈할 라이드 집어등의 수중 조도 분포 분석과 비슷한 방식으로 진 행되었으며 2.2.1과 2.2.2에서 조사한 해수의 투과 특성 및 굴절률 또한 동일하게 반영되었다.

\section{1. 평판형 엘이디 집어등 모델링}

본 논문에서는 소비전력은 $296 \mathrm{~W}$, 광 출력은 $93.2 \mathrm{~W}$ 인 평 판형 엘이디 집어등이 사용되었다. 평판형 엘이디 집어등은 Fig. 8과 같이 실린더 형 렌즈로 구성되어 있으며 배광각의 반치 폭은 90도이다. 동해의 소산계수에 따른 엘이디의 수심 별 스펙트럼 분포는 Fig. 9와 같다.

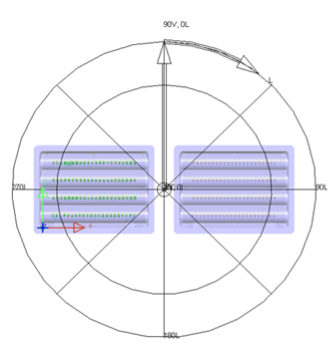

(a)

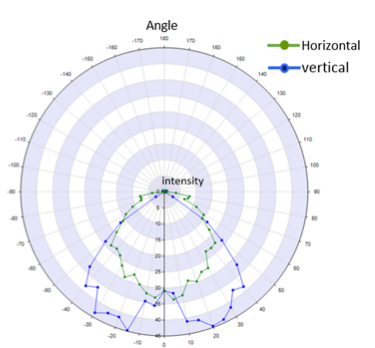

(b)
FIG. 8. (a) Layout and (b) Light distribution of Plate-LED source attached cylindrical lens.

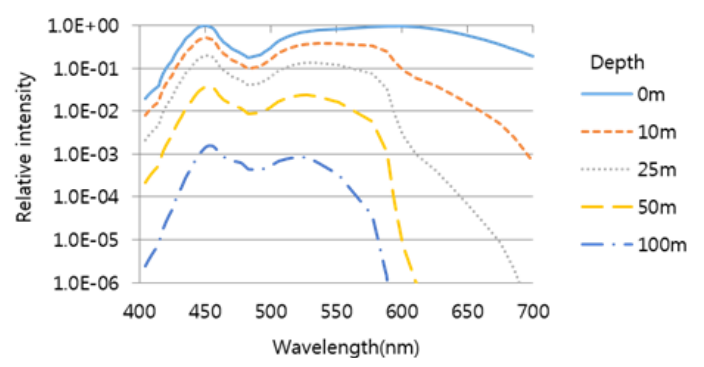

FIG. 9. Spectrum transmittance of LED source based on attenuation coefficient(k) of the Type-II. 


\section{2. 메탈할라이드 집어등과 평판형 엘이디 집어등의 수 중 조도 분포 비교}

Fig. 10처럼 평판형 엘이디 광원을 사용한 어선의 집어등 배치는 2층 2 열로 총 160 개를 배치하였으며, 엘이디 집어등

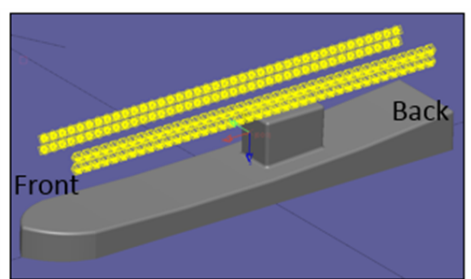

(a)

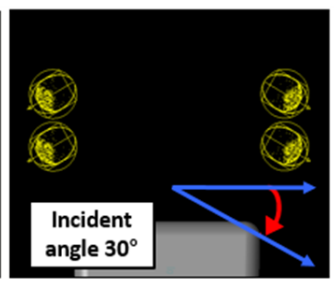

(b)
FIG. 10. (a) Layout of the ship using the Plate-LED sources and (b) Incident angle of the Plate-LED sources.

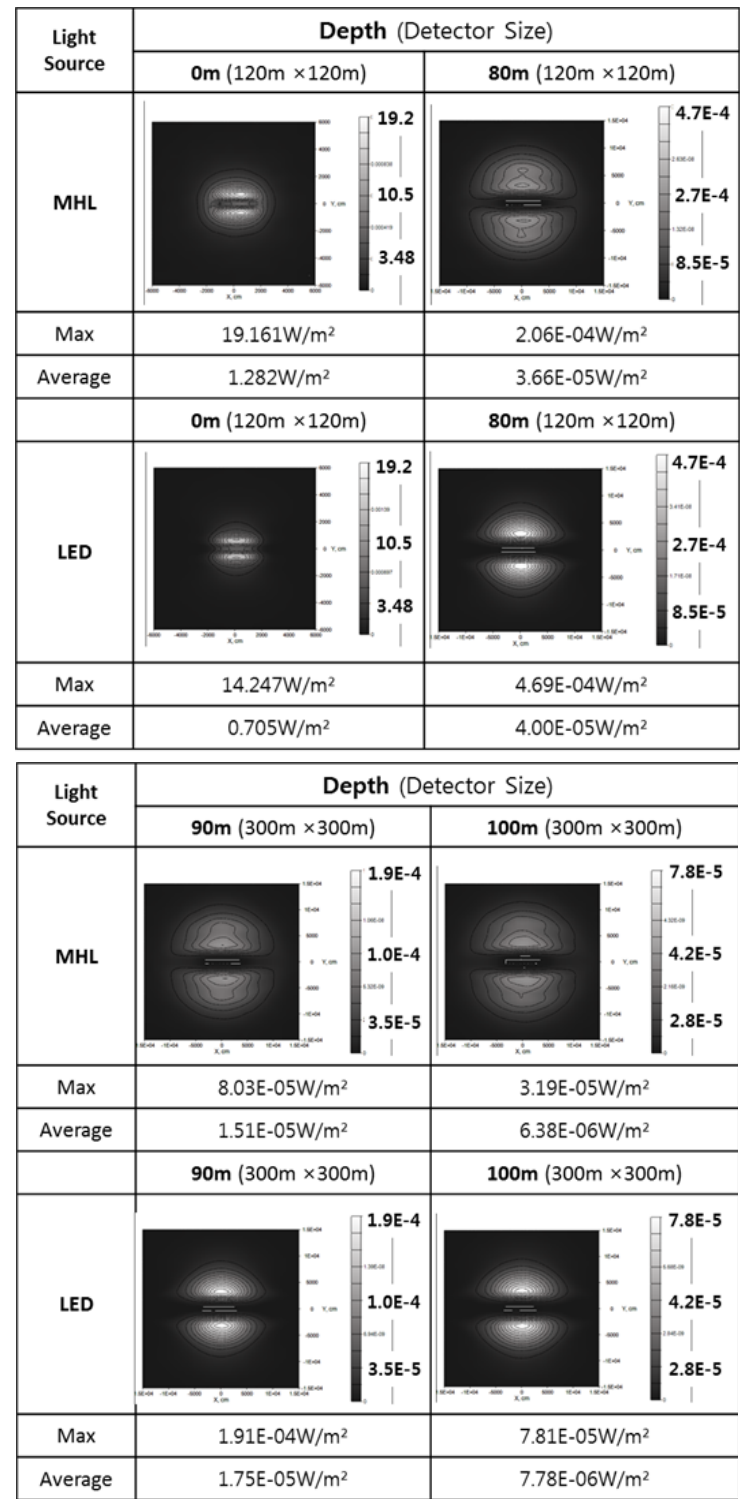

FIG. 11. Irradiance distribution comparison of MHL and LED by depth.
의 출력이 메탈할라이드 집어등에 비해 낮기 때문에 수심별 조도 값을 높이기 위해 평판형 엘이디 집어등의 해수면 입사 각을 30 도로 설정하였다. 이 30 도는 메탈할라이드 집어등과 조도 값을 맞추며 최대 조도 분포를 갖는 각도이다. 집어등 과 수표면 부터의 높이와 그 외 위치조건은 메탈할라이드 집 어등과 동일하며 해수 투과 및 굴절률 특성 또한 동일한 조 건으로 시뮬레이션하였다.

메탈할라이드 집어등을 사용한 어선의 조도 분포와 평판형 엘이디 집어등을 사용한 어선의 조도 분포 비교는 Fig. 11과 같이 최대조도와 평균조도를 나타내었다. 같은 수심에서의 메 탈할라이드 집어등 조도 분포와 엘이디 집어등의 조도 분포를 쉽게 비교할 수 있도록 같은 수심에서의 명암별 조도 값을 일 치 시켜 비교 하였고 횡단면 조도 분포 또한 비교하였다.

시뮬레이션 결과 조도 분포의 비교는 Fig. 12 의 예와 같이 어선의 앞, 뒤 음영지역과 전체적인 평균조도를 비교하였다. 특히, 엘이디 집어등을 사용한 어선의 경우 어선의 앞과 뒷 부분에서 빛의 분포가 부족한 것을 알 수 있었다. Fig. 13은

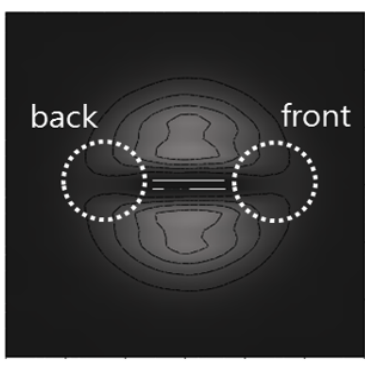

$<\mathrm{MHL}>$

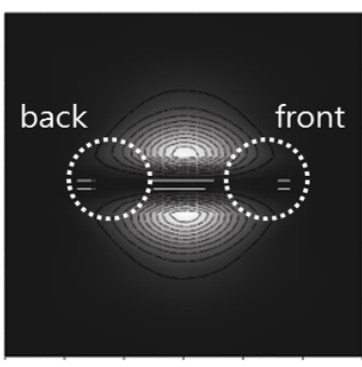

$<$ LED $>$
FIG. 12. Irradiance distribution comparison of MHL and LED at $70 \mathrm{~m}$.

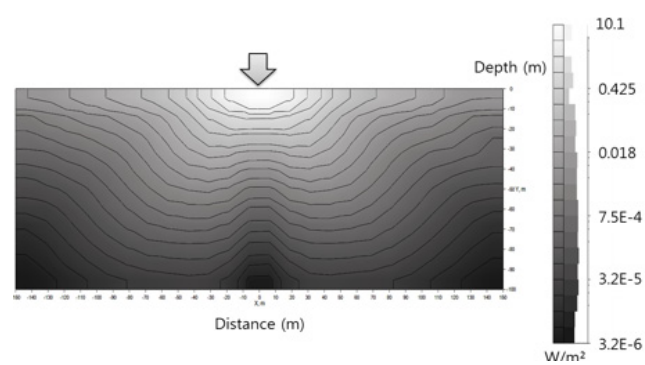

(a)

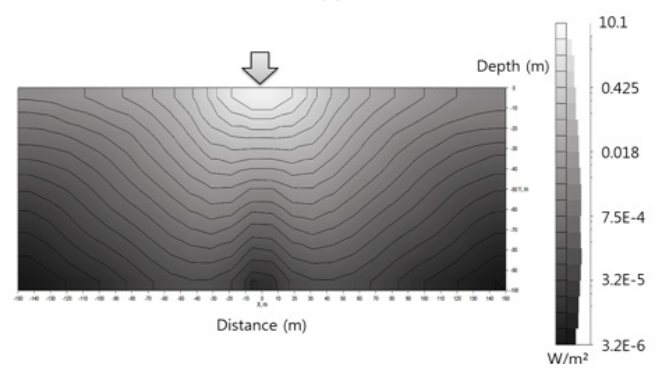

(b)

FIG. 13. Transverse cross section irradiance distribution comparison of (a) MHL and (b) LED. 
메탈할라이드 집어등과 엘이디 집어등의 횡단면 수심별 조 도 분포 이다. 어두울수록 낮은 조도 값을 의미하며 화살표 는 어선의 위치를 의미한다. 엘이디 집어등의 경우가 메탈할 라이드 집어등보다 배 중심 부근이 더 밝은 것을 알 수 있다. 원인으로는 메탈할라이드 집어등보다 엘이디 집어등의 좁은 배광특성으로 판단되며, 좁은 배광특성을 보완하기 위해 메 탈할라이드 집어등과 엘이디 집어등을 혼용 배치하고 설치 조건을 변경하여 시뮬레이션을 진행하였다.

\section{IV. 메탈할라이드 집어등과 엘이디 집어등의 혼용 배치 시뮬레이션}

\section{1. 메탈할라이드 집어등과 엘이디 집어등의 혼용 배치와} 설치 조건

메탈할라이드 집어등과 엘이디 집어등을 조합한 경우, 배 치구조와 해수면 입사각을 변수로 하여 기존 메탈할라이드 집어등과의 수중 조도 분포를 Fig. 14 와 같이 3 가지 type별
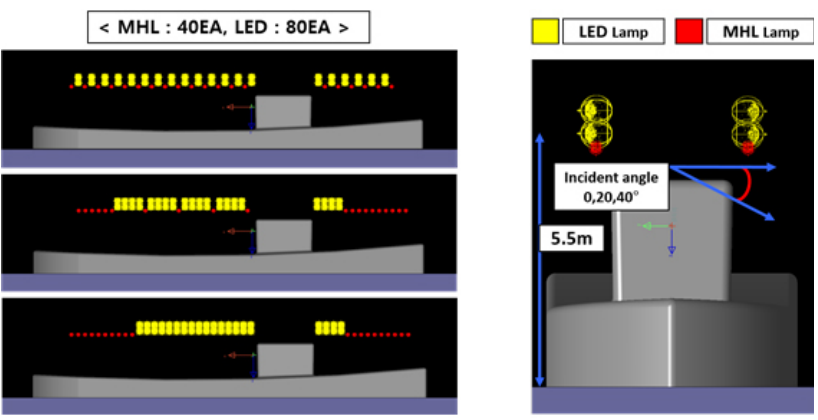

FIG. 14. MHL and LED combination by type and incident angle.
로 나누어 분석하였고 엘이디 집어등에 의한 해수면 입사각 도별 조도분포의 변화를 알아보기 위해 각도를 0 도, 20 도, 40도 세 가지로 구분하였고 LED 집어등의 안전 및 요구사 항에 의거하여 40 도 이상의 해수면 입사각은 안전규정상 제 한되었다. ${ }^{[8]}$

A type은 기존의 일반적인 메탈할라이드 집어등과 엘이디 집어등의 혼용배치 방식이고 메탈할라이드 집어등과 엘이디 집어등이 번갈아가면서 배치되어 있다. B type과 C type은 배의 앞, 뒤에 음영지역 ${ }^{[9]}$ 이 생기는 것을 줄이기 위하여 배광 각이 넓은 메탈할라이드 집어등을 배의 양 끝단에 점차적으 로 집중 설치한 방식이다. B type은 전 후면에 메탈할라이드 집어등을 각각 12 개와 20 개씩 배치하였으며 중간에는 평판

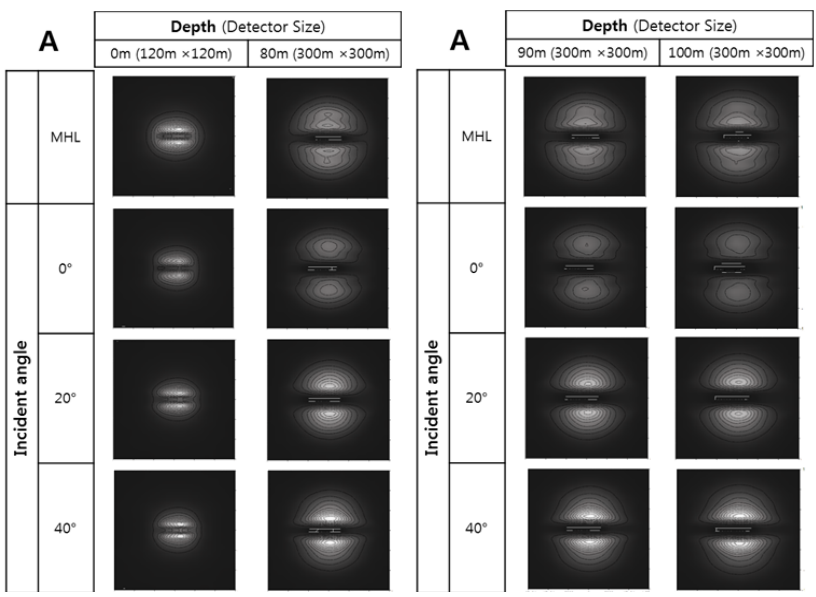

FIG. 15. Irradiance distribution of Type A by incident angle and depth.

TABLE 4. Irradiance results of Type A by incident angle and depth

\begin{tabular}{|c|c|c|c|c|c|c|}
\hline \multirow{2}{*}{$\begin{array}{l}\text { Light } \\
\text { source }\end{array}$} & \multirow{2}{*}{$\begin{array}{c}\text { Incident } \\
\text { angle }\end{array}$} & \multirow{2}{*}{$\begin{array}{c}\text { Irrdiance } \\
\left(\mathrm{W} / \mathrm{m}^{2}\right)\end{array}$} & \multicolumn{4}{|c|}{ Depth } \\
\hline & & & Surface & $10 \mathrm{~m}$ & $25 \mathrm{~m}$ & $50 \mathrm{~m}$ \\
\hline \multirow{2}{*}{ MHL } & & Max & 19.161 & 1.889 & 0.147 & $5.00 \mathrm{E}-03$ \\
\hline & & Average & 1.282 & 0.236 & 0.020 & $5.88 \mathrm{E}-04$ \\
\hline \multirow{7}{*}{ A Type } & \multirow{2}{*}{$0^{\circ}$} & Max & 13.360 & 1.368 & 0.117 & $4.20 \mathrm{E}-03$ \\
\hline & & Average & 0.849 & 0.157 & 0.013 & 4.04E-04 \\
\hline & \multirow{2}{*}{$20^{\circ}$} & Max & 17.114 & 1.754 & 0.146 & $6.28 \mathrm{E}-03$ \\
\hline & & Average & 0.931 & 0.177 & 0.016 & $5.04 \mathrm{E}-04$ \\
\hline & \multirow{2}{*}{$40^{\circ}$} & Max & 17.451 & 1.857 & 0.167 & $7.25 \mathrm{E}-03$ \\
\hline & & Average & 0.989 & 0.189 & 0.017 & $5.54 \mathrm{E}-04$ \\
\hline & & & $70 \mathrm{~m}$ & $80 \mathrm{~m}$ & $90 \mathrm{~m}$ & $100 \mathrm{~m}$ \\
\hline \multirow{2}{*}{ MHL } & & Max & $5.88 \mathrm{E}-04$ & $2.06 \mathrm{E}-04$ & 8.03E-05 & $3.19 \mathrm{E}-05$ \\
\hline & & Average & $9.01 \mathrm{E}-05$ & $3.66 \mathrm{E}-05$ & $1.51 \mathrm{E}-05$ & $6.38 \mathrm{E}-06$ \\
\hline \multirow{6}{*}{ A Type } & \multirow{2}{*}{$0^{\circ}$} & Max & 4.34E-04 & $1.48 \mathrm{E}-04$ & $5.45 \mathrm{E}-05$ & $2.05 \mathrm{E}-05$ \\
\hline & & Average & $6.16 \mathrm{E}-05$ & $2.49 \mathrm{E}-05$ & $1.02 \mathrm{E}-05$ & $4.27 \mathrm{E}-06$ \\
\hline & \multirow{2}{*}{$20^{\circ}$} & Max & 7.71E-04 & 2.93E-04 & $1.12 \mathrm{E}-04$ & $4.51 \mathrm{E}-05$ \\
\hline & & Average & $8.17 \mathrm{E}-05$ & $3.40 \mathrm{E}-05$ & $1.44 \mathrm{E}-05$ & $6.19 \mathrm{E}-06$ \\
\hline & \multirow{2}{*}{$40^{\circ}$} & Max & $9.57 \mathrm{E}-04$ & $3.62 \mathrm{E}-04$ & $1.46 \mathrm{E}-04$ & $5.91 \mathrm{E}-05$ \\
\hline & & Average & $9.13 \mathrm{E}-05$ & $3.83 \mathrm{E}-05$ & $1.64 \mathrm{E}-05$ & $7.11 \mathrm{E}-06$ \\
\hline
\end{tabular}


형 엘이디 집어등 4 개당 1 개씩 교차 배치하였다. C type은 전 후면에 각각 메탈할라이드 집어등을 20 개씩 배치하였다. 그리고 각각의 type에서 엘이디 집어등의 해수면입사각을 0 도, 20도, 40도로 변화시켜 수심별 조도분포 변화를 살펴보았다. 각각에 대한 결과는 아래와 같으며, Fig. 11 과 같은 방법으로 같은 수심에서의 명암별 조도 값을 일치 시켜 비교 하였다. 수 심별 횡단면 조도 또한 Fig. 13과 같은 방법으로 비교하였다.

각 type별로 엘이디 집어등의 해수면 입사각에 따른 수심 별 조도 값을 비교해본 결과, 모든 type에 대해서 40도로 하 였을 때 메탈할라이드 집어등의 평균 조도 값과 가장 유사한 수치를 나타내었다. 그리고 약 $25 \mathrm{~m}$ 지점까지는 메탈할라이 드 집어등의 조도 값이 우수하지만 그 이후는 메탈할라이드 집어등과 엘이디 집어등을 혼용한 경우가 더 높은 조도 값을 나타내었으며 해수면 입사각이 높아질수록 그러한 경향은 심화되었다.

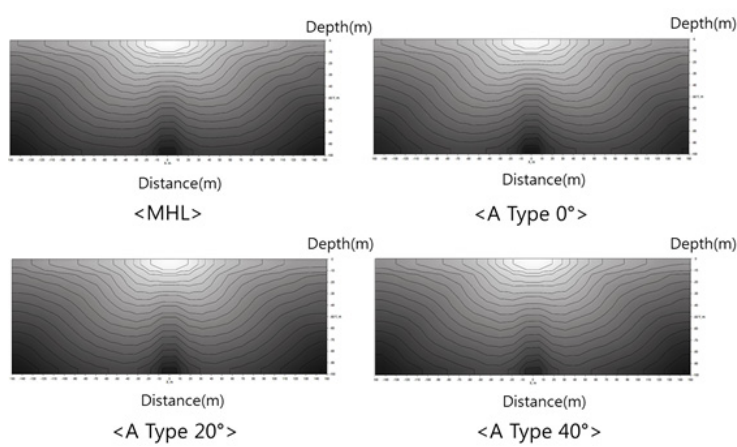

FIG. 16. Transverse cross section irradiance distribution comparison of MHL and A Type by incident angle.
수심 $50 \mathrm{~m}$ 이후의 조도 값은 매우 작은 값으로 떨어지기 때문에 $50 \mathrm{~m}$ 이후부터는 조도 값보다는 조도 분포의 비교가 의미 있을 것으로 사료된다. 위 분석을 통해 40도 각을 설정 하였을 경우 조도 분포가 메탈할라이드 집어등 어선과 근접 해지는 것을 확인하였고 조도분포 비교를 위해 type별로 40 도인 경우만 정리하여 Fig. 21에 나타내었다.

해수로 입사되어지는 빛의 경계면이 엘이디 집어등만 설치 한 선박처럼 앞과 뒤에서 일그러진다면 빛에 민감한 오징어 어군이 앞뒤로 이탈이 일어날 것이고, 이는 어획성능의 저하 를 일으키는 요인이 될 수 있다. ${ }^{[7]}$ Fig. 21에 수심 $100 \mathrm{~m}$ 지 점에서의 빛무리의 지름(회색 점선 화살표)과 음영지역(흰색 화살표)의 폭을 표시하였고 그 값을 Table 7에 정리하였다.

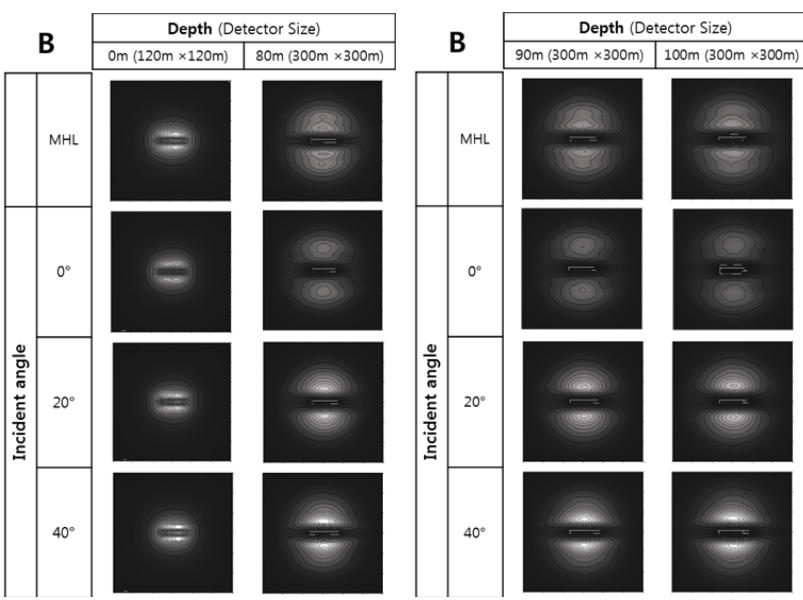

FIG. 17. Irradiance distribution of Type B by incident angle and depth.

TABLE 5. Irradiance results of Type B by incident angle and depth

\begin{tabular}{|c|c|c|c|c|c|c|}
\hline \multirow{2}{*}{$\begin{array}{c}\text { Light } \\
\text { source }\end{array}$} & \multirow{2}{*}{$\begin{array}{c}\text { Incident } \\
\text { angle }\end{array}$} & \multirow{2}{*}{$\begin{array}{l}\text { Irrdiance } \\
\left(\mathrm{W} / \mathrm{m}^{2}\right)\end{array}$} & \multicolumn{4}{|c|}{ Depth } \\
\hline & & & Surface & $10 \mathrm{~m}$ & $25 \mathrm{~m}$ & $50 \mathrm{~m}$ \\
\hline \multirow{2}{*}{ MHL } & & Max & 19.161 & 1.889 & 0.147 & $5.00 \mathrm{E}-03$ \\
\hline & & Average & 1.282 & 0.236 & 0.020 & $5.88 \mathrm{E}-04$ \\
\hline \multirow{6}{*}{ В Type } & \multirow{2}{*}{$0^{\circ}$} & Max & 11.597 & 1.345 & 0.116 & $4.15 \mathrm{E}-03$ \\
\hline & & Average & 0.869 & 0.161 & 0.014 & $4.12 \mathrm{E}-04$ \\
\hline & \multirow{2}{*}{$20^{\circ}$} & Max & 16.271 & 1.786 & 0.149 & $6.36 \mathrm{E}-03$ \\
\hline & & Average & 0.951 & 0.180 & 0.016 & $5.13 \mathrm{E}-04$ \\
\hline & \multirow{2}{*}{$40^{\circ}$} & $\operatorname{Max}$ & 16.663 & 1.906 & 0.170 & $7.35 \mathrm{E}-03$ \\
\hline & & Average & 1.009 & 0.192 & 0.017 & $5.62 \mathrm{E}-04$ \\
\hline & & & $70 \mathrm{~m}$ & $80 \mathrm{~m}$ & $90 \mathrm{~m}$ & $100 \mathrm{~m}$ \\
\hline \multirow{2}{*}{ MHL } & & Max & $5.88 \mathrm{E}-04$ & $2.06 \mathrm{E}-04$ & 8.03E-05 & $3.19 \mathrm{E}-05$ \\
\hline & & Average & $9.01 \mathrm{E}-05$ & $3.66 \mathrm{E}-05$ & $1.51 \mathrm{E}-05$ & $6.38 \mathrm{E}-06$ \\
\hline \multirow{6}{*}{ B Type } & \multirow{2}{*}{$0^{\circ}$} & Max & 4.29E-04 & $1.47 \mathrm{E}-04$ & $5.58 \mathrm{E}-05$ & $2.08 \mathrm{E}-05$ \\
\hline & & Average & $6.28 \mathrm{E}-05$ & $2.54 \mathrm{E}-05$ & $1.04 \mathrm{E}-05$ & 4.34E-06 \\
\hline & \multirow{2}{*}{$20^{\circ}$} & Max & $7.78 \mathrm{E}-04$ & $2.96 \mathrm{E}-04$ & $1.11 \mathrm{E}-04$ & $4.52 \mathrm{E}-05$ \\
\hline & & Average & $8.30 \mathrm{E}-05$ & $3.45 \mathrm{E}-05$ & $1.46 \mathrm{E}-05$ & $6.28 \mathrm{E}-06$ \\
\hline & \multirow{2}{*}{$40^{\circ}$} & Max & $9.69 \mathrm{E}-04$ & $3.65 \mathrm{E}-04$ & $1.45 \mathrm{E}-04$ & $5.94 \mathrm{E}-05$ \\
\hline & & Average & $9.25 \mathrm{E}-05$ & $3.88 \mathrm{E}-05$ & $1.66 \mathrm{E}-05$ & $7.20 \mathrm{E}-06$ \\
\hline
\end{tabular}


TABLE 6. Irradiance results of Type $\mathrm{C}$ by incident angle and depth

\begin{tabular}{|c|c|c|c|c|c|c|}
\hline \multirow{2}{*}{$\begin{array}{c}\text { Light } \\
\text { source }\end{array}$} & \multirow{2}{*}{$\begin{array}{c}\text { Incident } \\
\text { angle }\end{array}$} & \multirow{2}{*}{$\begin{array}{c}\text { Irrdiance } \\
\left(\mathrm{W} / \mathrm{m}^{2}\right)\end{array}$} & \multicolumn{4}{|c|}{ Depth } \\
\hline & & & Surface & $10 \mathrm{~m}$ & $25 \mathrm{~m}$ & $50 \mathrm{~m}$ \\
\hline \multirow{2}{*}{ MHL } & & Max & 19.161 & 1.889 & 0.147 & $5.00 \mathrm{E}-03$ \\
\hline & & Average & 1.282 & 0.236 & 0.020 & $5.88 \mathrm{E}-04$ \\
\hline \multirow{6}{*}{ C Type } & \multirow{2}{*}{$0^{\circ}$} & Max & 11.471 & 1.335 & 0.115 & 4.12E-03 \\
\hline & & Average & 0.880 & 0.163 & 0.014 & 4.17E-04 \\
\hline & \multirow{2}{*}{$20^{\circ}$} & Max & 15.914 & 1.805 & 0.150 & $6.36 \mathrm{E}-03$ \\
\hline & & Average & 0.954 & 0.181 & 0.016 & $5.08 \mathrm{E}-04$ \\
\hline & \multirow{2}{*}{$40^{\circ}$} & Max & 16.331 & 1.928 & 0.172 & 7.35E-03 \\
\hline & & Average & 1.019 & 0.194 & 0.017 & $5.67 \mathrm{E}-04$ \\
\hline & & & $70 \mathrm{~m}$ & $80 \mathrm{~m}$ & $90 \mathrm{~m}$ & $100 \mathrm{~m}$ \\
\hline \multirow{2}{*}{ MHL } & & Max & $5.88 \mathrm{E}-04$ & $2.06 \mathrm{E}-04$ & $8.03 \mathrm{E}-05$ & $3.19 \mathrm{E}-05$ \\
\hline & & Average & $9.01 \mathrm{E}-05$ & $3.66 \mathrm{E}-05$ & $1.51 \mathrm{E}-05$ & $6.38 \mathrm{E}-06$ \\
\hline \multirow{6}{*}{ C Type } & \multirow{2}{*}{$0^{\circ}$} & Max & $4.26 \mathrm{E}-04$ & $1.47 \mathrm{E}-04$ & $5.50 \mathrm{E}-05$ & $2.04 \mathrm{E}-05$ \\
\hline & & Average & $6.36 \mathrm{E}-05$ & $2.57 \mathrm{E}-05$ & $1.05 \mathrm{E}-05$ & 4.40E-06 \\
\hline & \multirow{2}{*}{$20^{\circ}$} & Max & 7.78E-04 & $2.95 \mathrm{E}-04$ & $1.11 \mathrm{E}-04$ & 4.51E-05 \\
\hline & & Average & $8.18 \mathrm{E}-05$ & $3.39 \mathrm{E}-05$ & $1.43 \mathrm{E}-05$ & $6.14 \mathrm{E}-06$ \\
\hline & \multirow{2}{*}{$40^{\circ}$} & Max & $9.71 \mathrm{E}-04$ & 3.64E-04 & $1.46 \mathrm{E}-04$ & $5.95 \mathrm{E}-05$ \\
\hline & & Average & 9.33E-05 & $3.91 \mathrm{E}-05$ & $1.67 \mathrm{E}-05$ & $7.25 \mathrm{E}-06$ \\
\hline
\end{tabular}

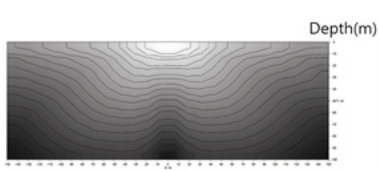

Distance $(m)$

$<\mathrm{MHL}>$

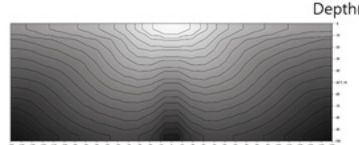

Distance $(m)$

$\left\langle\right.$ B Type $\left.20^{\circ}\right\rangle$

FIG. 18. Transverse cross section irradiance distribution comparison of MHL and B Type by incident angle.

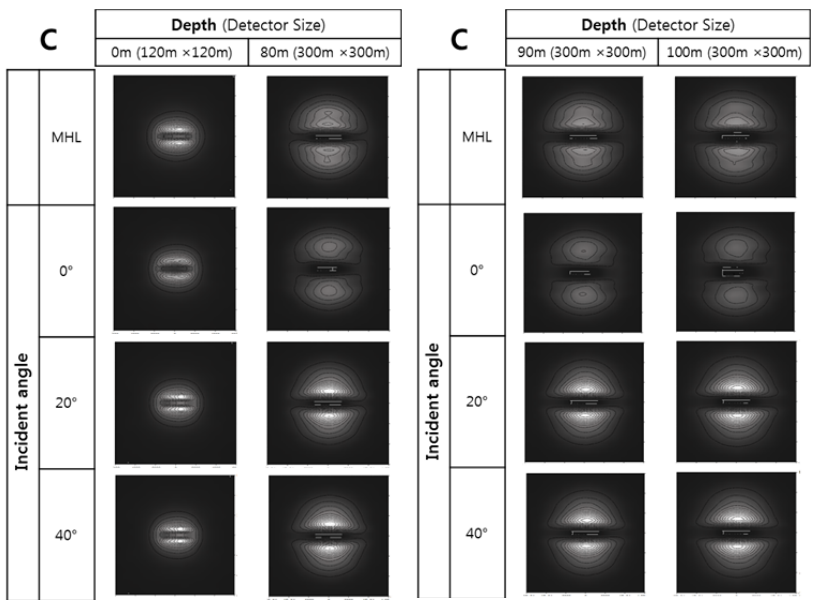

FIG. 19. Irradiance distribution of Type B by incident angle and depth.

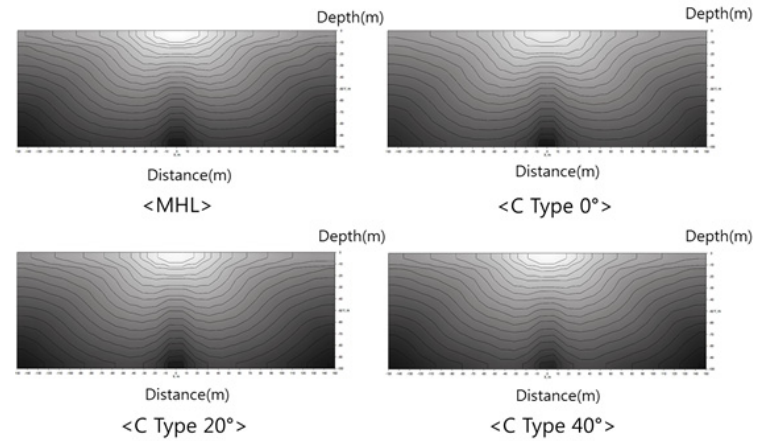

FIG. 20. Transverse cross section irradiance distribution comparison of MHL and $\mathrm{C}$ Type by incident angle.

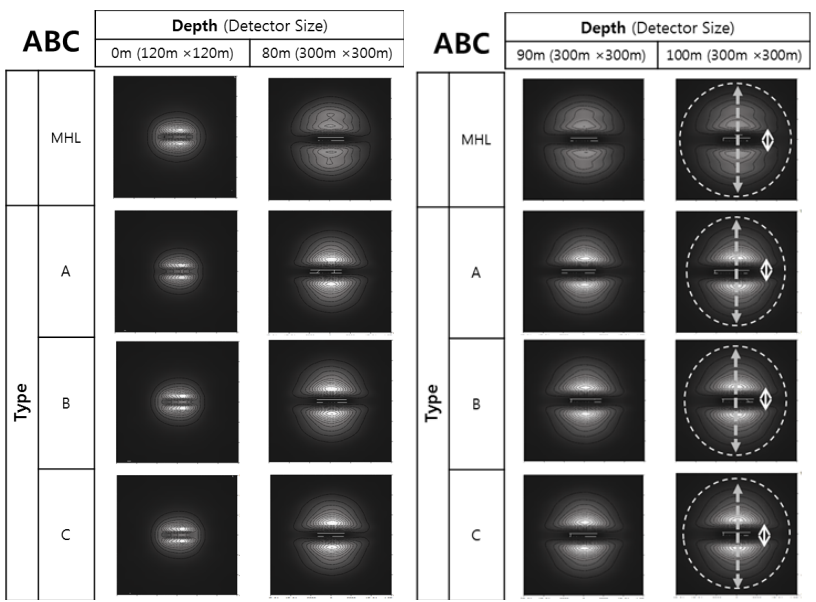

FIG. 21. Irradiance distribution of three types at $40^{\circ}$ by depth. 
TABLE 7. Light distribution diameter and shadow zone width at $100 \mathrm{~m}$

\begin{tabular}{cccc}
\hline \hline $\begin{array}{c}\text { Light } \\
\text { source }\end{array}$ & $\begin{array}{c}\text { Light distribution } \\
\text { diameter }\end{array}$ & $\begin{array}{c}\text { Shadow zone } \\
\text { width }\end{array}$ \\
\hline \multicolumn{2}{c}{ MHL } & $284.9 \mathrm{~m}$ & $24.40 \mathrm{~m}$ \\
\hline \multirow{3}{*}{ Type } & $\mathrm{A}$ & $243.19 \mathrm{~m}$ & $23.06 \mathrm{~m}$ \\
\cline { 2 - 4 } & $\mathrm{B}$ & $244.09 \mathrm{~m}$ & $23.2 \mathrm{~m}$ \\
\cline { 2 - 4 } & $\mathrm{C}$ & $252.1 \mathrm{~m}$ & $23.6 \mathrm{~m}$ \\
\hline
\end{tabular}

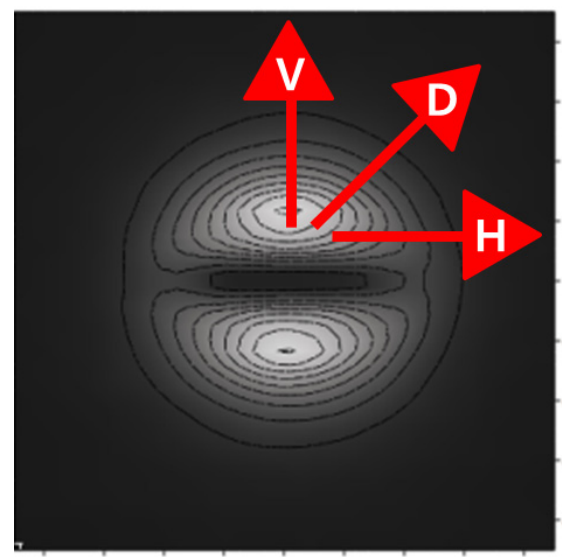

FIG. 22. The direction image of irradiance detection line.

음영지역의 폭은 큰 변화가 없고 빛무리의 지름은 C type 이 가장 근접하였다. $\mathrm{A}, \mathrm{B}, \mathrm{C}$ type 중 메탈할라이드 집어등 을 가장 많이 배의 양 끝단으로 집중 배치한 $\mathrm{C}$ type의 수심 별 조도 분포가 기존 메탈할라이드 집어등의 수심별 조도 분 포와 가장 유사함을 보였다.

빛이 멀리 퍼지는 정도를 수치적으로 알아보기 위해 Fig. 22 처럼 수심 $80 \mathrm{~m}$ 지점에서 수직선(Vertical), 대각선(Diagonal), 수평선(Horizontal) 방향의 조도를 선형적으로 2차원 그래프 로 나타내었다.

Fig. 23에서 특히 수평선 방향의 경우 메탈할라이드 광원 과의 조도가 동일해지는 교차점이 가장 멀리 위치하였고 40 도인 경우가 빛이 멀리 가는 것을 확인하여 각 타입별 해수 면 입사각이 40 도인 경우만을 비교하였다.

Fig. 23에서 수직선과 대각선 방향으로는 엘이디 광원만을 사용한 어선이 배 주변의 광량이 높다는 것을 알 수 있으며 조합배치한 세가지 타입의 경우 유의미한 차이가 없음을 확 인하였다.

그러나 수평선 방향의 경우 메탈할라이드 광원과의 동일한 조도지점 교차점을 볼 때, $\mathrm{C}$ 타입의 40 도인 경우가 가장 멀 리 있어 배의 전 후 방향으로 빛이 멀리 퍼진 다는 것을 확 인할 수 있다.

따라서, 수평선 $(\mathrm{H})$ 라인을 수심 $90 \mathrm{~m}, 100 \mathrm{~m}$ 지점으로 확 대하여 Fig. 24에 나타내었다.

$90 \mathrm{~m}, 100 \mathrm{~m}$ 지점에서도 같은 경향을 나타내었으며 역시

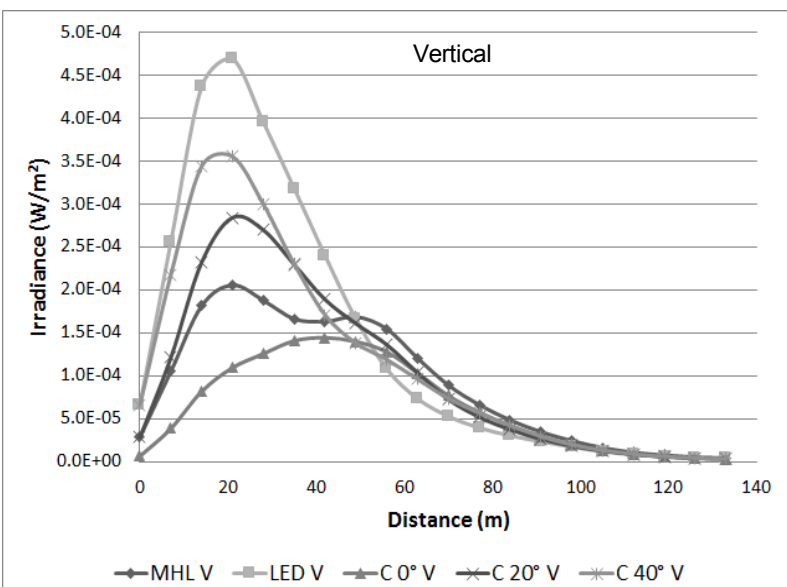

(a)

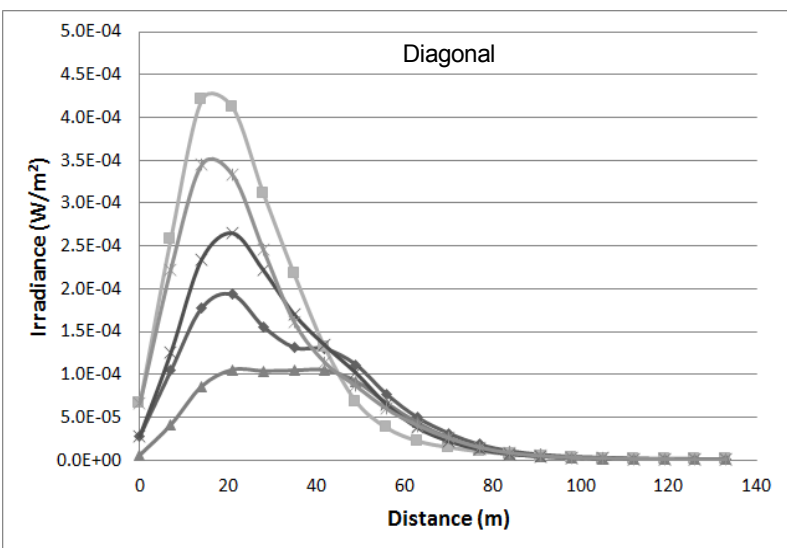

$\rightarrow \mathrm{MHLD} \rightarrow-\mathrm{LEDD} \rightarrow \mathrm{C} 0^{\circ} \mathrm{D} \approx \mathrm{C} 20^{\circ} \mathrm{D} \approx \mathrm{C} 40^{\circ} \mathrm{D}$

(b)

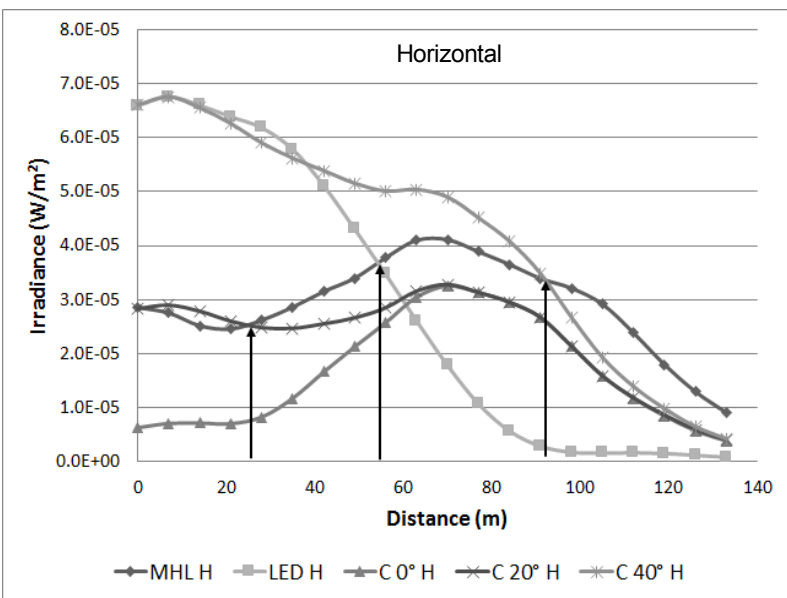

(c)

FIG. 23. The irradiance data of $\mathrm{C}$ type according to incident angle at $80 \mathrm{~m}$ water level (a) vertical, (b) diagonal, (c) horizontal.

수평방향으로 $\mathrm{C}$ 타입의 빛이 멀리 퍼지는 것을 확인하였고, 빛의 도달거리가 메탈할라이드 어선에 근접하여 오징어의 유 인능력이 보다 우수할 것이라고 추측하였다. 


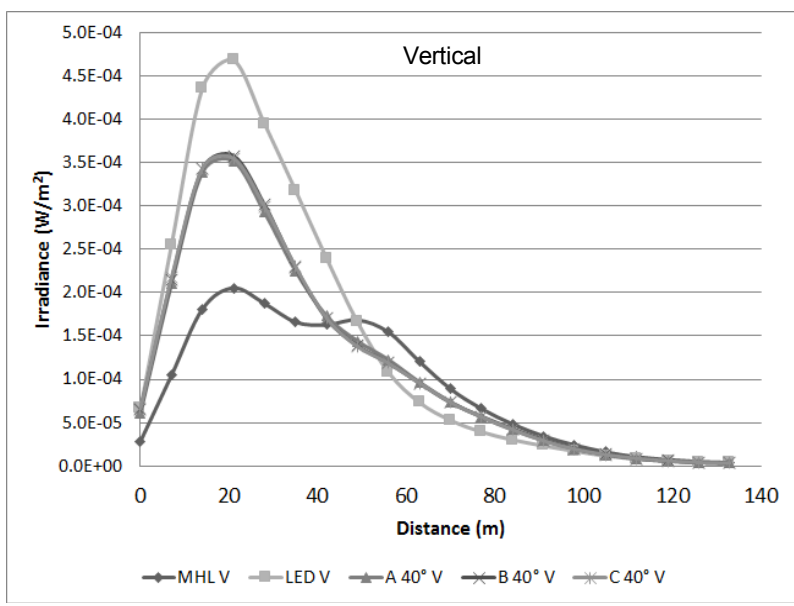

(a)

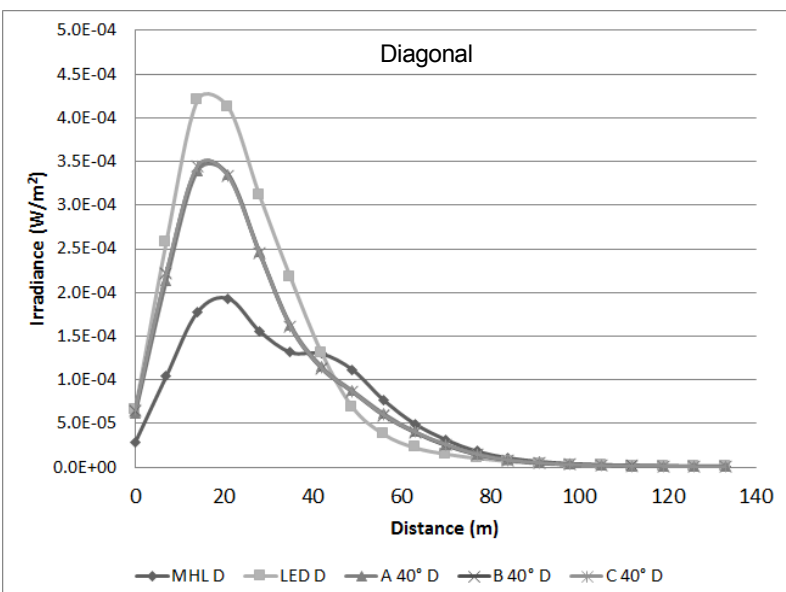

(b)

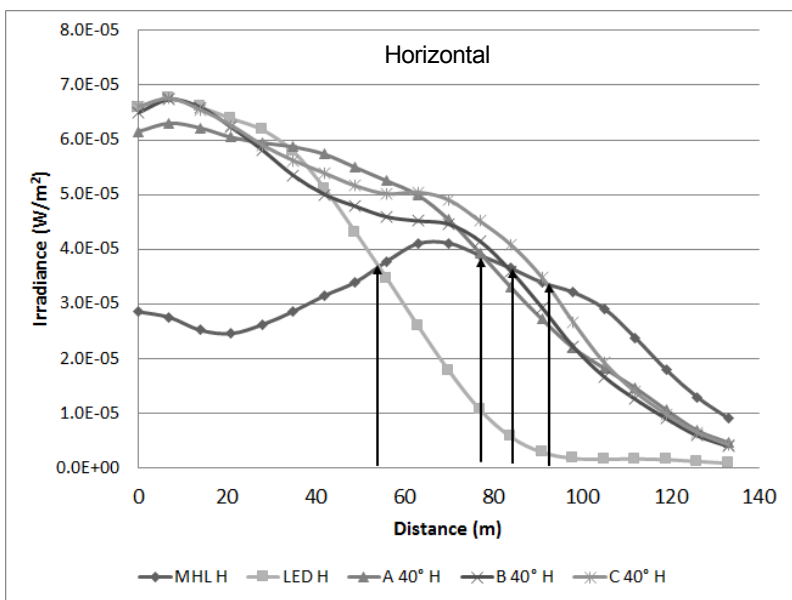

(c)

FIG. 24. The irradiance data of incident angle according to each type at $80 \mathrm{~m}$ water level (a) vertical, (b) diagonal, (c) horizontal.

\section{V. 결 론}

실제의 메탈할라이드 집어등을 사용하는 40 톤급 어선에 대하여 메탈할라이드 집어등을 모델링하고 배치하였다. 그리

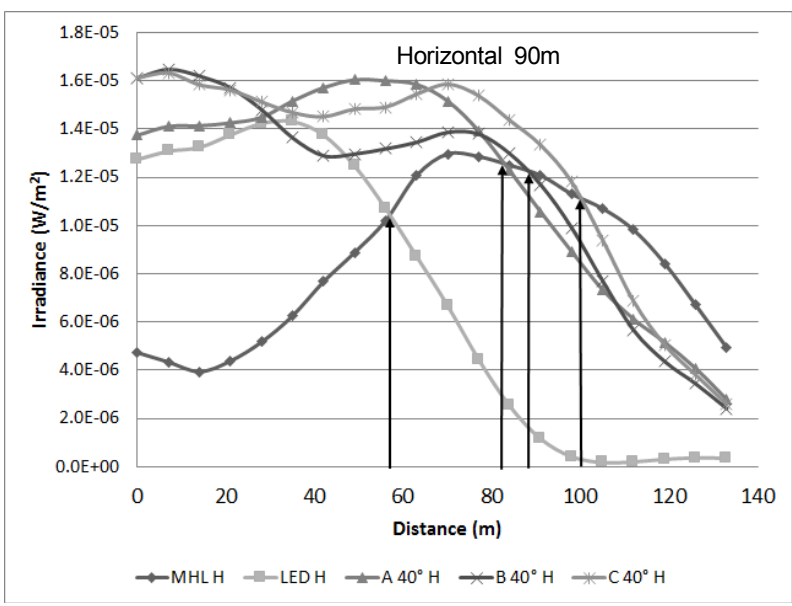

(a)

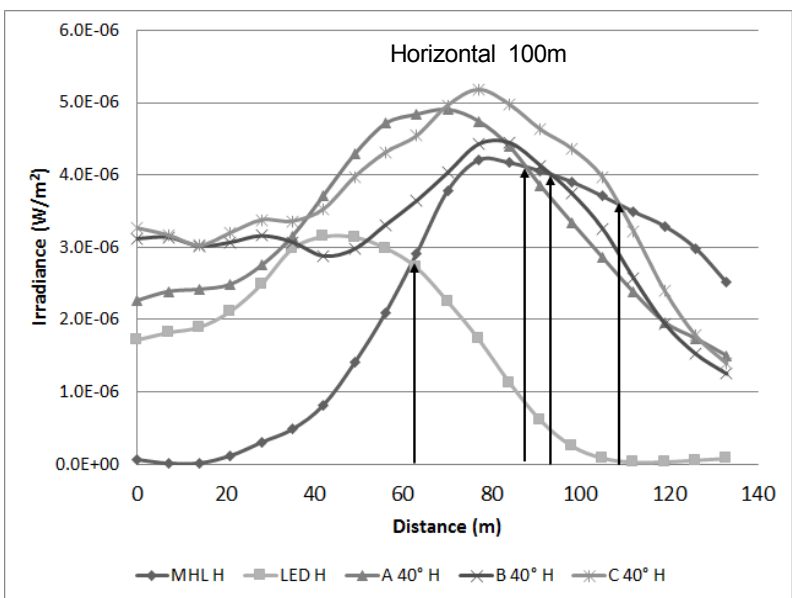

(b)

FIG. 25. The irradiance data of horizontal distance at (a) $90 \mathrm{~m}$, (b) $100 \mathrm{~m}$ waterlevel.

고 우리나라 오징어 조업 철 동해안의 광 특성 데이타를 반 영한 해수를 구현하였고 그에 따른 수심별 조도 분포 결과를 분석하였다.

이를 기준으로 유사한 수심별 조도 분포를 갖기 위한 2층 2 열 배치의 평판형 엘이디 집어등으로 시뮬레이션을 진행하 였고 그 결과는 해당 수심별 조도 값은 메탈할라이드 어선과 근접하였으나, 조도 분포는 상대적으로 작음을 확인할 수 있 었다. 이는 기존의 평판형 엘이디 집어등은 메탈할라이드 집 어등이 가지고 있는 배광특성과는 달리 높은 지향성으로 인 한 배광특성에 기인한 것으로 메탈할라이드 집어등에 비해 상대적으로 좁은 면적에 빛이 조사되어진다는 것을 알 수 있 었다.

본 연구에서는 기준 메탈할라이드 집어등 조도 분포와의 배광차이를 극복하기 위하여 평판형 엘이디 집어등과 메탈 할라이드 집어등을 혼용 배치하고 설치 조건을 변경하여 시 뮬레이션을 진행하였다. 그 결과 최적의 배치 및 설치 조건 은 C type의 해수면 입사각이 40 도인 경우라 결론지었다. 


\section{감사의 글}

본 연구는 국립수산과학원(채낚기용 고효율 집어시스템 기술개발, RP-2014-FE-023)의 지원에 의해 수행되었습니다.

\section{References}

1. I. S. Chun and B. M. Jung, "Study on fishery analysis by omnidirectional light ditribution characteristics of LED fishing light," in Proc. KIIEE Annual Spring Conference (Jecheon, Korea, May 2012), pp. 65-67.

2. J. Driscoll and P. Tyedmers, "Fuel use and greenhouse gas emission implications of fisheries management: The case of the new england atlantic herring fishery," Marine Policy 34, 353-359 (2010).

3. SYNOPSYS, Inc., "Lighttools version 8.1," http://optics. synopsys.com/lighttools/

4. N. G. Jerlov, Marine Optics (Elsevier, New York, USA, 1976), pp. 132-138.
5. R. W. Austin and G. Halikas, "The index of refraction of seawater," SIO Ref. No. 76-1, Scripps Institution of Oceanography La Jolla California USA (1976).

6. Korea Hydrographic and Oceanographic Administration (Korea ocean observing and forecasting system Statistical data Ulleungdo Water temperature and Salt concentration, 2013) http://sms.khoa.go.kr/koofs/kor/observation/obs_past_searc h_statistic.asp.

7. S. J Choi and H. Arakawa, "Relationship between the catch of aquid, Todarodes pacificus STEENSTRUP, according to the jigging depth of hooks and Underwater illumination in squid jigging boat," J. Korean Fish. Soc. 34, 624-631 (2001).

8. The Safety Information \& Performance of LED Jigging Lamp SPS-KLEDA L 1004 : Page 7 (2010).

9. I. S. Chun, B. M. Jung, and D. H. Jung, "LED fishing lamp structure of discharge heat that has the fluid circulation system and LED fishing lamp in which that is applied," Korea Patent 10-1311761 (2013). 